\title{
Income Diversification Among Rural Households in the Mekong River Delta, Vietnam: A Look Back at the Economic Transition Period
}

\author{
Long Hau Le ${ }^{1} \&$ Tan Nghiem Le ${ }^{1}$ \\ ${ }^{1}$ College of Economics, Can Tho University, Vietnam \\ Correspondence: Long Hau Le, College of Economics, Can Tho University, Vietnam.
}

Received: February 22, 2020

Accepted: April 18, 2020

Online Published: June 16, 2020

doi:10.5430/rwe.v11n3p124

URL: https://doi.org/10.5430/rwe.v11n3p124

\begin{abstract}
Based on five Living Standard Measurement Surveys (LSMSs) conducted over a thirteen year period (1993 to 2006), this paper examined patterns of income diversification in rural areas of the Mekong River Delta (MRD). In terms of quintile specific patterns, over the period 1993-2006, across all quintiles there is a sharp reduction in the time spent on farm self-employment (9.4 to 20.7 percentage points) and an increase in the share of time spent on non-farm wage employment (11.3 to 14.3 percentage points). While there are differences across quintiles, the patterns are broadly similar across expenditure groups and it does not seem that the increase in non-farm wage employment is restricted to particular groups of households. As may be expected given the changes in the activity-allocation pattern, over time, there is an increase in reliance on non-farm wage income by about 6.4 to 11.4 percentage points across quintiles. The interesting aspect is that while households in the poorest income quintiles still continue to rely heavily on agriculture related income (61.2 versus 39.9 percent for the richest quintile) they experience similar patterns of change in terms of a movement from relying on farm income to non-farm sources of income.
\end{abstract}

Keywords: Vietnam, Mekong River Delta, income diversification, household

JEL classification code: D13, D14, D31, G31, G50

\section{Introduction}

Based on the potential role of income diversification in stabilizing incomes and alleviating rural poverty, governments in several developing countries have devoted increasing attention to output diversification policies (Petit and Barghouti 1992). Vietnam is not an exception and in the follow-up to the launch of the renovation process (1988), the government has devised and implemented various economic reforms to stimulate economic development and output diversification. Among others, specific objectives of the reforms for rural development are to create more jobs, to raise agricultural and rural industry-related income, and to develop services and off-farm activities. In other words, these policies are designed to directly and indirectly stimulate the process of income diversification in Vietnam in general and in rural areas in particular.

As has been widely recorded, the early reforms led to significant economic achievements in the post-1990 period and between 1993 and 1998 the country experienced a high level of economic growth as well as a sharp reduction in poverty. Between 1993 and 1998 the economy grew at an annual rate of 9.8 percent, which may be compared with a 5.1 percent growth in 1990 (GSO 2002). Remarkably, the country's overall poverty rate declined from 58 percent in 1993 to 37 percent in 1998 (Haughton 2001).

This period also witnessed noticeable improvements in agriculture, the sector where Vietnam's program of renovation was initiated. Between 1986 and 1998 a range of institutional changes provided households with long term land-use leases, better access to agricultural input and output markets, and more autonomy in decision making on production. Of the various institutional changes, the removal of all restrictions on internal trading in rice, increases in the rice export quota and the unrestricted import of fertilizers directly resulted in a sharp drop in the price of fertilizer and significant increase in the price of rice, especially in southern Vietnam (Benjamin and Brandt 2002). These sharp price changes strengthened the effects of the 1988 reforms - which were marked by decentralization of decision making - and affected the supply and marketing decisions of farm households and exerted positive effects on their incomes and welfare (Benjamin and Brandt 2002).

After 1998, Vietnam's renovation program continued with reforms along multiple dimensions with agriculture and 
rural development remaining one of the most important concerns for generating sustainable growth and poverty reduction. During the period 1998-2006, Vietnam's economic growth rate has remained high and stable, and by 2006, poverty had fallen to 15.5 percent. The structure of GDP has changed and over the years there has been an increase in the share of industry and a decline in agriculture, showing a clear transformation towards a more industrialized and modernized economy. These changes imply a reduction in the importance of agriculture and over time, suggest an ongoing process of diversification at the macro level.

At a micro level, reforms implemented under Vietnam's renovation framework may be expected to lead to income diversification mainly through indirect channels. That is, reforms are likely to have influenced the decision making of households towards production and engagement in certain income earning options, which, in turn, leads to income diversification. Besides reforms, other variables such as changes in consumption behaviour, and variability in markets for factors of production and output, may also lead to changes in household decision-making.

While a number of authors and empirical papers have examined the pattern of poverty reduction in Vietnam (for instance, Glewwe et al. 2004, Minot et al. 2003, UNDP 2004, World Bank 1999), relatively little attention has been paid to income diversification issues. Furthermore, the existing work on diversification in Vietnam examines patterns of diversification for the entire country. As pointed out by Barrett and Reardon (2001) and Ellis (2000), the character of income diversification varies across space and over time. While country-wide studies have the advantage of scope they are not able to delve too deeply into a single region. For instance, despite these studies, little is known about how policy changes required by the renovation in Vietnam determined the livelihoods or income structure of rural households in the Mekong River Delta (MRD). Accordingly, the aim of this paper is not to examine possible effects of either a specific reform or a variable but to acquire an understanding of the patterns and trends in income diversification among rural households. In other words, it provides an in-depth investigation of various aspects of income diversification in the rural MRD. Its strategy is to use micro (household level) data from the LSMSs conducted in Vietnam over the period 1993-2006 to examine the patterns and the trends of income diversification. This paper exploits the cross-section and panel elements of the data.

The paper is organized as follows. The following section provides a summary of diversification-related issues in the literature. Sections 3 and 4 provide information on the data and methods of analysis. Section 5 discusses cross-sectional and temporal patterns of income diversification among rural households in the MRD. Section 6 concludes.

\section{Literature Review}

Empirical studies in this field have based their analysis on at least one of the following five definitions of income diversification.

First, this is the simplest definition and possibly closest to the meaning of the word. That is, diversification is referred to a process by which the presence of multiple income sources is created (Minot et al. 2006). The number of income sources that each household has at a given point in time is used as a measure of income diversity while the difference in the number of income sources that one household has at different points in time indicates the level of income diversification pursued by that household over that corresponding period. Accordingly, households with more income sources are treated as households with higher levels of diversity in income and the greater the increase in the number of sources over time the greater the increase in diversification over time. This indicator, the number of income sources, has the advantage that it is simple to understand and provides an easily visible picture of income diversification. However, as the focus is solely on the number of sources, this conceptualization of income diversification treats every source of income equally instead of taking into account the importance of, or the income share from each of the sources. This is its main weakness and due to this, it is not widely used, or is used as a complementary indicator, in empirical studies in this field. In their study, Minot et al. (2006) employ this measure along with other measures to examine the patterns and determinants of income diversification among rural households in Vietnam.

To overcome the above-mentioned weakness, an approach that takes into consideration both the number of income sources and the contribution of each source to total household income may be used. In this conceptualization, income diversification is understood as a process in which households increase not just the number of sources but also achieve a greater balance in terms of the relative share of the various income sources in their portfolio (Ellis 2000, Minot et al. 2006). This conceptualization is operationalized by using the following indices: the original Herfindahl index, the inverse Herfindahl index, and the Simpson index. (Note 1) Although the underlying idea of this approach sounds useful, these two-dimensional indices are not able to reveal the type of diversification pursued by different households that have the same value of the indices or within a single household at different points in time. They are an inappropriate measure for any study in which understanding diversification into a given source, for example non-farm 
employment, is the central concern. Possibly, these disadvantages make the definition less preferred. Examples of research using this conceptualization include Ellis (2000), Joshi (2003) and Minot et al. (2006).

The third, and also the most widely used definition relates to non-farm employment. At the household-level, income diversification is defined as a process in which rural households increase their employment and income from the non-farm sector (Barrett and Reardon 2001, Barrett et al. 2001, Davis and Bezemer 2003, Ellis 2000, Lanjouw and Feder 2001). Regarding this, either the share of time spent on or the share of earnings from non-farm activities is used to highlight the importance of non-farm income in a household's livelihood. A number of papers have adopted this conceptualization including Ellis (2000), Escobal (2001), Abdulai and CroleRees (2001), van de Walle and Cratty (2004) and Minot et al. (2006).

A fourth definition of income diversification refers to commercialization. In the words of Minot et al. (2006: 5), "a less ambiguous term ... is agricultural commercialization" and that "is sometimes defined as the process of switching from subsistence production of staple crops to commercial production of a wider range of agricultural commodities and to non-farm activities." With this conceptualization, income diversification is referred to in terms of the level and change over time in the proportion of home produced agricultural product that is sold. This measure is useful as it provides a sense of the level of market integration and is an outcome of farmers' production and sales decisions. However, it does not provide a complete portrait of income diversification in rural areas - where there are a number of households who are not farmers and whose earnings are solely from non-farm employment.

Finally, income diversification is used and defined by Minot et al. (2006: 6) as "the process of switching from low-value crop production to high-value crops, livestock, and non-farm activities". The distinction between "high value" and "low value" is based on the net revenue per hectare or per day of labour from each of the activities undertaken by rural households. This criterion can be viewed as an extension of the use of "labour productivity" or "capital productivity". The underlying argument for this approach is that "high value" options are more likely to be used by better-off than worse-off households, while the opposite pattern is expected for "low value" options.

Without concerning about the popularity in use of each measure across a number of related studies, it is clear that there is no superiority of one measure of income diversification over the other. Each has advantages and disadvantages relative to the other. In addition, measurement is derived from the way in which income diversification is conceptualized, which is more likely dependent on the interested aspects of income diversification in each study. This can be resulted in the unstandardized definition of diverisification in the literature. In a review of various empirical studies that used income approach, Reardon (1997) comments that defining diversification in terms of income may be the most suitable approach. Barrett and Reardon (2001) point out that selecting income as an object of analysis will give the best picture of diversification if diversification motives are clearly distinguished between choice and necessity. From the side of an alternative approach, activity diversification which is measured by either shares of time allocation from the input side or income from the output side can be adopted as a suitable measure of income diversification if researchers purposively ignore unearned income sources and define diversification as participation in income-generating activities (Lanjouw and Feder 2001). Barrett and Reardon (2001) also go on to add that, given the advantages and disadvantages of each indicator, it may be better to simultaneously use several indicators to provide a more complete idea of the extent of diversification (Barrett and Reardon 2001).

As introduced, this paper purposively acquires an understanding of the patterns and trends in income diversification among rural households in a single region of Vietnam. For this sake, it plans to take all useful measures to capture various aspects of income diversification while it still sets a place for special attention to assessing income diversification from the input side, in terms of time spent on different activities, and from the output side, in term of income shares attributable to different sources.

\section{Data}

The data used for the analyses in this paper is drawn from five rounds of the Living Standards Measurement Surveys (LSMS) in Vietnam, known as Vietnam Living Standard Survey (VLSS), and integrated with information drawn from other official sources collected by the Vietnam General Statistics Office (GSO). These five cross-section data sets (1993, 1998, 2002, 2004 and 2006) spanning a thirteen year period allow an assessment of cross-sectional patterns of the factors that determine household income from farm self-employment and non-farm wage employment.

\section{Methods}

\subsection{Operationalization of Income Diversification}

In order to highlight the role of farm self-employment but also that of other sources, the income share-from the output side - and the share of hours worked (activity approach) — from the input side — across different sources are used to examine patterns of diversification in the specific context of the MRD. Income diversification is understood as a 
process by which rural households choose to increase their income share and the earning time spent from a source other than cropping production, for example non-farm wage employment. Additionally, the number of income sources and the proportion of agricultural output sold are also used to shed light on the patterns of diversification. For reasons provided earlier, two-dimensional indices are not a useful choice and the unavailability of data precludes the use of the "high value" versus "low value" activity approach. In short, analyses of the temporal and cross-sectional patterns of income diversification among rural households in the MRD in this paper is based on four types of indicators: share of income from various earning sources, share of working time spent on various activities, number of income sources and the proportion of agricultural output that is sold.

The analysis presented below relies on the household as the unit of analysis. To be more specific, a household is a unit comprising members who have shared lodging, income and expenditure for at least 6 months during the 12 months preceding the survey (GSO 2006c). Accordingly, analysis of income shares and time allocated to different activities is based on total household income and total household working time which are defined as the sum of income earned and the amount of working time spent on various activities by each household member over the past 12 months.

\subsection{Classification of Household Income Sources}

As developed and displayed in Figure 1, each household in this study can obtain income from two types of employment, that is, self-employment and wage employment and through transfers and other income. Self-employment is further divided into farm self-employment and off-farm self-employment while wage employment is sub-grouped into farm wage employment and non-farm wage employment. There are two sources under the farm self-employment sub-category, namely crop production, and livestock and aquaculture. Overall, household income can be obtained from seven income sources.

Farm self-employment consists of crop, livestock, and aquaculture related activities which are carried out on "household-run farms". Off-farm self-employment refers to self-employed activities other than those related to crops, livestock and aquaculture production that takes place away from household-run farms. Off-farm self-employment includes processing of any kind of goods for sale whose input materials can be either home-produced agricultural commodities or bought from markets. It also includes the provision of agricultural services which are provided on farms not run by the household.

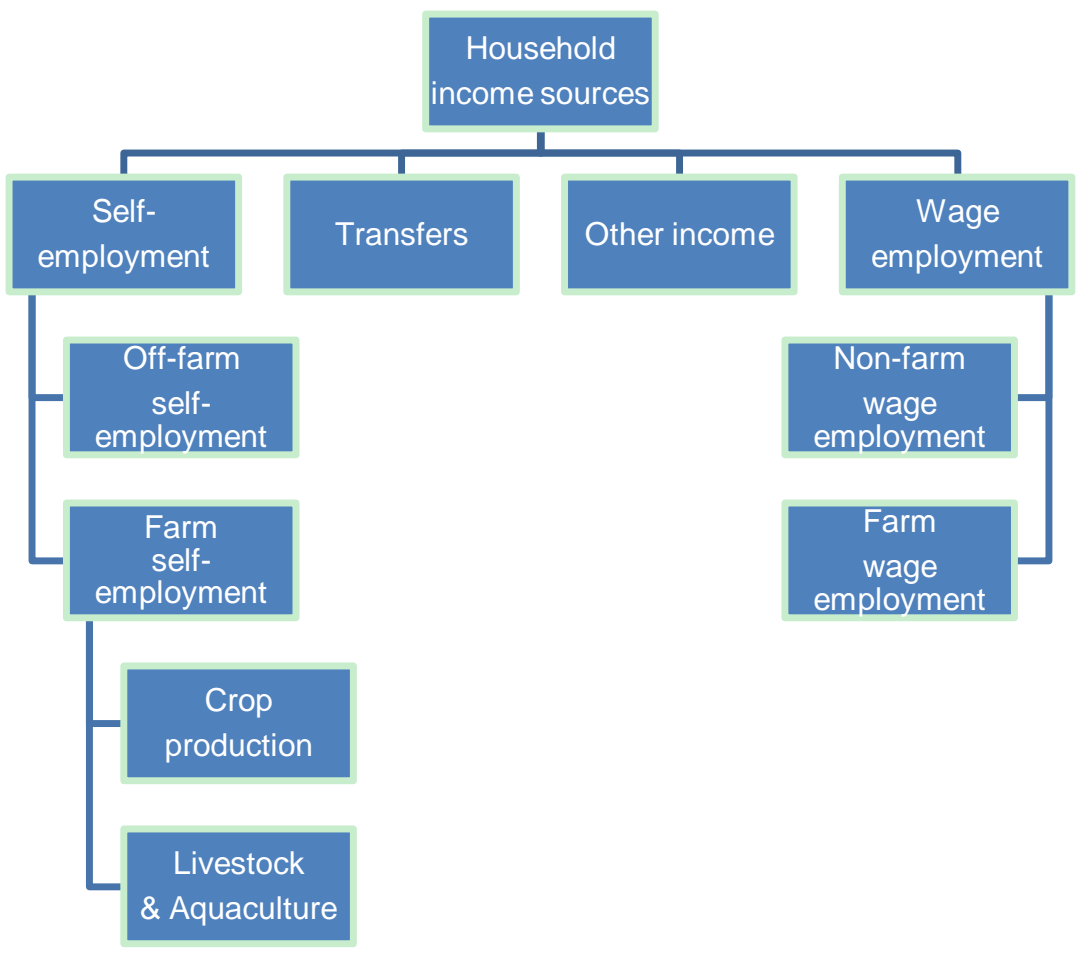

Figure 1. Classification of household income sources 
Farm wage employment refers to agricultural related activities (including aquaculture) which involve the supply of paid labour on farms other than those owned by household members. Non-farm wage employment encompasses a wide range of work for wages and covers employment in public administration, in large corporations, small manufacturing factories, those working in construction and transportation and professionals in various sciences, education and training.

Farm self-employment consists of crop, livestock, and aquaculture related activities which are carried out on "household-run farms". Off-farm self-employment refers to self-employed activities other than those related to crops, livestock and aquaculture production that takes place away from household-run farms. Off-farm self-employment includes processing of any kind of goods for sale whose input materials can be either home-produced agricultural commodities or bought from markets. It also includes the provision of agricultural services which are provided on farms not run by the household.

Farm wage employment refers to agricultural related activities (including aquaculture) which involve the supply of paid labour on farms other than those owned by household members. Non-farm wage employment encompasses a wide range of work for wages and covers employment in public administration, in large corporations, small manufacturing factories, those working in construction and transportation and professionals in various sciences, education and training.

\section{Calculation of income}

While it is relatively straightforward to compute income from activities such as farm wage employment, non-farm wage employment and transfers, in the case of crop production, livestock and aquaculture, and off-farm self-employment, the term "income" refers to the amount of net revenues from each activity. (Note 2) The general formula for computing income from each of these three sources is in terms of subtracting total costs of production, excluding labour inputs by household members, from the total value of production. The total value of a production activity, in turn, consists of two components, that is, the value of sales and the value of home uses (food and animal feed). The exclusion of the costs of labour inputs by household members in assessing these three sources of income follows van de Walle's (1998: 128) argument that this is "largely because of uncertainty about how to measure the opportunity cost of family labour."

More specifically, crop income is defined as the sum of income from annual, perennial and forestry crops earned by a household over the past twelve months preceding the survey. It is a bit more complicated to assess the crop income for the LSMSs conducted in 1990s than for the LSMSs conducted in the 2000s. For the first two surveys, the share of crop income is computed on the basis of information recorded in two modules: agricultural production and expenditure. For each crop, the sale value, the value of crop by-products and the value of home consumption are available in the corresponding module. The value of home-produced agricultural crop that is used as input materials to produce goods for sale is calculated by multiplying the average price of that commodity being sold with the total quantity being used. Therefore, the total value of crop production is obtained. Then, the total amount of all crop production costs that are paid for seeds, fertilizers, pesticides, land rental, hired labour, storage, and marketing, are deducted from the total value of sale and home uses of all crops to get the cropping income. For the survey conducted in the 2000s, these required pieces of information are directly available in the dataset.

The combined account of income from livestock and aquaculture is assessed as follows. For the LSMS 1993 and 1998, data about the sales value of animal, animal products (milk and eggs) and aquaculture are directly obtained from the datasets; the value of home consumption of meat from animals and animal products as well as that of aquatic products are found in the expenditure section of the questionnaire. In terms of costs, the purchases of young animals and the mixed costs of producing livestock and aquaculture are also available in the datasets. With these pieces of information, the combined income from livestock and aquaculture is computed in the same way as for crop income. For the LSMS conducted in the 2000s, the combined income from livestock and aquaculture is obtained by adding up the separate information available for each of these sources of income. The data for each of these sources of income contains information on home consumption and production costs and supports the computation of income earned from this source..

In the case of off-farm self-employment, income is the sum of all amounts earned by a household from all self-employed activities over the past twelve months. In the LSMS 1993 and 1998, data on the amount of money that the household retains after paying for hired labour and other business expenses as well as the value of home-consumed enterprise goods and home processing of home-produced crops are collected to estimate the net revenue from this activity. Data for computing the amount of net earnings from supplying agricultural services are also directly available. Subsequently, the total income from off-farm self-employment is reached. Although there is a difference in the 
questionnaire designed for LSMS 2000s compared with LSMS 1990s, the same way of computing is used to obtain income from this source.

Incomes earned from farm and non-farm wage employment are calculated in a similar manner. In the LSMSs, data collected in the employment section includes information on the industry in which each activity pursued by the household or household member is carried out, and this information is used to differentiate the total time allocated to and income earned from agriculture and non-agricultural wage employment. In terms of calculation, each type of wage income is defined as the sum of annual earnings in wages and bonuses from the most time-consuming job (the main job) and the second most time-consuming job (the secondary job) over the past twelve months.

There is further information on income earned from jobs other than the primary and the secondary job but the breakdown of these jobs into different sectors is not available and income from such sources is categorized as "other income". (Note 3)

Transfers capture the total amount of all private transfers, which are remittances and value of in-kind presents from people who are not household members at the time of surveys, which all household members received over the past twelve months. These amounts are unrelated to sources such as funds or programs related to government poverty programs and NGO, private or international assistance, pensions, interests of savings and loans, lottery winnings, and rental income, which are, in turn, summed up in the "other income" account.

In the LSMS questionnaires, there is a separate section to directly collect information about the money received from the one-time sales of assets such as buildings, home productive assets, vehicles, gold, or jewellery. These amounts are windfall gains and are not included in the definition of income.

Total household income is obtained by summing up these various amounts and the income share from each source is obtained by dividing the amount of income earned from that source by the total household income for each of the seven sources.

\section{Calculation of total household working time}

On the input side, in principle we would like to have the share of hours worked in all seven corresponding sources of income. Unfortunately, such detailed information is not available and we can only divide the allocation of household labour time into four categories. These are farm self-employment, off-farm self-employment, farm wage employment, and non-farm wage employment. The first group consists of all crops, livestock and aquaculture production while the last three are similar in scope and definition to their income counterparts.

As mentioned above, the employment module in each LSMS provides information on hours worked in a main and secondary job for every individual in the household. Based on these data, the amount of earning hours spent in each of the four employment groups as well as the total amount of earning hours for each household is obtained. Subsequently, the share of time spent in each of the four types of employment activities is computed. (Note 4)

Calculation of the ratio of agricultural commercialization

Agricultural commercialization refers to the proportion of agricultural output that is sold. This is defined in terms of the ratio of sales value to the total value of all agricultural output produced by a household in the last twelve months. Agricultural output includes crops, livestock and aquaculture production.

\subsection{Analytical Methods}

This paper relies on univariate and bivariate analysis to display cross-sectional and temporal patterns in income diversification at the household-level. To capture differences between the rich and the poor or, more broadly, across different levels of household welfare the paper provides an account of overall diversification patterns and an analysis of patterns conditional on per-capita expenditure (PCE) quintiles.

For both descriptive and analytical purposes, although income per capita may seem to be the most obvious candidate, expenditure is argued to be the best indicator in terms providing a more accurate picture of household welfare. Dollar and Glewwe (1998) point out that heavily indebted households with large amounts of current earned income may be thought of as having high living standard levels but their consumption may be low as a consequence of using income to pay for debts. Second, savings may allow households to enjoy high levels of consumption even if their current incomes experience a short-term decline.

\section{Performance of Income Diversification in the MRD}

\subsection{Measures of Diversity in the Number of Income Sources}

Table 1 displays the average number of income sources of rural households conditional on household per capita 
expenditure-based quintiles. Figures show that in 1993, an average household had 3.61 income sources in 1993, while the most diversified household had 7 sources of income. Over time, there is limited variation in the number of sources and between the end-points of the period under consideration (1993-2006), the size of increase in overall income sources is small (0.37), although statistically significant, indicating an increase in income diversification over the entire period. (Note 5)

Table 1. Trends in income diversification, by the number of income sources

\begin{tabular}{|c|c|c|c|c|c|c|c|c|}
\hline \multirow{2}{*}{ uintiles } & \multicolumn{2}{|c|}{1993} & \multirow{2}{*}{$\begin{array}{c}1998 \\
\text { Mean SD. }\end{array}$} & \multicolumn{2}{|c|}{2002} & \multirow{2}{*}{$\frac{2004}{\text { Mean } S D .}$} & \multirow{2}{*}{$\frac{2006}{\text { Mean SD. }}$} & \multirow{2}{*}{$\frac{2006 / 1993}{\text { Diff.p-value }}$} \\
\hline & & DD. & & ean & $S D$. & & & \\
\hline & 3.51 & 1.10 & 3.711 .07 & 3.0 & 1.0 & 27 & 4. & 0 . \\
\hline 准 & 3.64 & 1.16 & 3 & 3. & 1.04 & & & \\
\hline id & 3.6 & 1.12 & 3.5 & 2.9 & 1.00 & 3. & 4. & 0 \\
\hline & 3.60 & .11 & 3.580 . & 2.8 & 1.04 & 3. & 3. & 92 \\
\hline & 3.60 & 1.05 & 3.491 .05 & 2.65 & 1.03 & 3.531 .07 & 3.7 & 193 \\
\hline verall & 3.61 & 1.11 & $\begin{array}{ll}3.59 & 1.00\end{array}$ & 2.92 & 1.04 & $3.87 \quad 1.12$ & 3.981 .12 & 0.370 .0000 \\
\hline
\end{tabular}

Note: The number of observation is $800,830,5079,1488$, and 1473 respectively for the $1993,1998,2002,2004$ and 2006 sample.

Source: Author's calculation from the LSMS 1993, 1998, 2002, 2004 and 2006.

In terms of cross-sectional patterns, the level of income diversity does not appear to differ across expenditure quintiles in 1993. As seen in Table 1, the average number of income sources for households in the 'poorest quintile' is 3.51 and it is the highest for those in the 'middle quintile' (3.68). None of the variations in this measure of income diversification across the five quintiles is statistically significant. This indicates that the rich and the poor are not different in terms of the level of diversity in income sources in 1993. This cross-sectional pattern of diversity remains unchanged in the 1998 sample. The lack of variation in this measure across expenditure quintiles in the MRD is different from the patterns for the country as a whole. According to Minot et al. (2006), in 1993 and in 1998, the pattern of diversity as measured by the number of income sources has an inverted $U$-shape indicating that households located in the middle quintiles have the largest number of sources of income while those at the ends of the distribution are not as diversified.

Beyond 1998, Table 1 shows a clear pattern of income diversity within individual cross-section samples. In 2002, 2004, and 2006, the average number of income sources is always the lowest for households in the 'richest quintile' while it is the highest for those in the first two quintiles indicating a higher level of income diversity amongst poorer households. The pattern of higher diversification amongst the poor provides support for the "push-distress diversification" strategy. The pattern observed in the MRD is different from patterns observed in other contexts. For example, in rural Zimbabwe in 1990/91 and 1995/96, richer households were more likely to rely on a larger number of income sources (Ersado 2006).

Across quintiles and across years, figures in the last column of Table 1 show another clear pattern of income diversification. Between 1993 and 2006, there is an increase in the number of income sources across expenditure quintiles but the increase is highest for the poorest households $(0.7)$, slightly less for the 'middle quintile' $(0.33)$ and for the 'richest quintile' there is no statistically significant increase in the number of income sources. The expansion of the number of income sources amongst poorer households suggests that diversification in Vietnam, at least on the basis of this measure, may be characterized as push-distress diversification.

\subsection{Measure of Diversity in Income Shares}

Table 2 provides information on overall patterns and trends of income diversification pursued by all households while Table 3 shows detailed patterns and trends across expenditure groups within and over the period 1993-2006.

As shown in the first column of Table 2, in 1993, crop income is the most important source of household income accounting for 32.7 percent of total household income. Off-farm business and farm wage employment take the second and third place accounting for 20.4 percent and 18.1 percent of household income, respectively. Aquaculture accounts for 12.2 percent of income while non-farm wages and transfers account for 7.2 and 3.4 percent respectively. The heavy 
reliance on crop production in particular and agricultural self-employed activities (crop, livestock and aquaculture production) in rural MRD is also found in a number of other developing countries. (Not e6)

Five years later, the contribution of crop income to total income in the MRD is somewhat higher at 39.5 percent-an increase of about 7 percentage points. As discussed earlier, due to internal and external trade liberalization over this period, there was a sharp increase in prices of agricultural commodities, especially rice, and the higher share of income from crops may be attributed to these price increases. Whether these changes also induced an increase in time devoted to cultivation of crops or should be viewed as essentially a price effect requires an examination of time allocation patterns, which appears in the following sub-section. As far as other income sources are concerned, there is a reduction in the contribution of off-farm business and farm wage work while the share of other income sources remains about the same.

In 2002, the share of crop income returns to the 1993 level and it remains the largest source of household income. The main change in 2002 versus the previous years is the sharp increase in the income share of non-farm wage employment. As displayed in Table 2, the income share from this source goes up to 13.6 percent in 2002 from around seven percent in both 1993 and 1998. Given the fluctuating prices of agricultural commodities, it is not clear whether these changes represent direct price effects or real outcomes of household decision-making process based at least partially on relative price incentives or signals, or both. (Note 7) This needs to be complemented by looking at time allocation patterns, as discussed in the next section. Nonetheless, the increased income share from non-farm wages is probably driven by better access to non-farm wage earning options and the expansion of non-farm enterprises in the MRD and in the industrial zones of the Southeast region as a consequence of the unified Enterprise Law introduced in 2000. (Note 8)

The expansion of the importance of non-crop sources of income continues in 2004. This expansion appears to be consistent with an increased level of diversity, measured by the number of income sources as already described in section 5.1. While crop income maintains its primacy its share drops to 27.9 percent, livestock and aquaculture, off-farm business, and farm wages each provide 13-15 percent of total household income in 2004. Non-farm wage income remains stable at 13.8 percent. The main change in 2004 is the sharp increase in the share of income from transfers in total household income which records a contribution of 11.3 percent in 2004, as compared to a share of 2-4 percent in earlier years. Analysis of the sources of these transfers shows that 95 percent of these transfers are internal and are remitted from urban to rural areas.

Table 2. Trends of income diversification, by income shares

\begin{tabular}{|c|c|c|c|c|c|c|}
\hline \multirow{2}{*}{ Income source } & 1993 & 1998 & 2002 & 2004 & 2006 & $2006 / 1993$ \\
\hline & Mean SD & $\overline{\text { Mean SD. }}$ & $\overline{\text { Mean SD. }}$ & \multicolumn{3}{|c|}{$\overline{\text { MeanSD. MeanSD. Diff. p-value }}$} \\
\hline $10 \mathrm{ps}$ & $.327 \quad .306$ & .395 .335 & $.324 \quad .330$ & .279 .301 & .259 .289 & -.068 .0000 \\
\hline ive & .122 .200 & .118 .216 & $.148 \quad .234$ & .139 .223 & .136 .227 & .014 .1290 \\
\hline Off-fa & .204 .297 & .169 .278 & $.164 \quad .289$ & .145 .258 & .153 .265 & -.051 .0001 \\
\hline Farm & .181 .285 & .133 .251 & .154 .266 & .127 .240 & .109 .222 & -.072 .0000 \\
\hline Non- & $.072 \quad .184$ & .069 .173 & $.136 \quad .257$ & .138 .250 & .161 .270 & 089.0000 \\
\hline Transf & .034 .125 & .037 .125 & .020 .108 & .113 .188 & .123 .198 & .089.0000 \\
\hline Other & .060 .129 & .079 .177 & .054 .138 & .058 .135 & .058 .127 & .002 .7214 \\
\hline
\end{tabular}

Note: The number of observation is 800, 830, 5079, 1488, and 1473 respectively for the 1993, 1998, 2002, 2004 and 2006 sample.

Source: Author's calculation from the LSMS 1993, 1998, 2002, 2004 and 2006.

The sharp increase in the share of income from transfers in this year is remarkable. However, in 1999 there was a change in internal migration restrictions which promoted an increase in migration from the rural areas of the MRD to urban areas and industrial zones of the Southeast. UNFPA (2007) estimates that in 2004, on average, migrants remitted between 10 to 17 percent of their income to their areas of origin. Accordingly, while it is a large jump as compared to the situation in 2002, the increase in the share of income from transfers in 2004 does not seem unreasonable.

In 2006, the pattern of income diversity observed in previous rounds tends to strengthen. The income share from crops and farm wages continues to decline, and they account for 25.9 percent and 10.9 percent of household income, 
respectively. In contrast, the contribution of income earned from non-farm wage employment increases to 16.1 percent of total income and by 2006 is higher than the share of off-farm business, further asserting the importance of non-farm wage employment. The increase in the income share from transfers remains stable at the 2004 level suggesting that the spike in income from transfers was not a temporary effect.

Over the entire period 1993-2006, there are two major temporal trends in diversification, which were also reflected in the macro background on income diversification mentioned in the introduction. First, there is a marked decline in the share of income from crops and farm wages. The share of these income sources declines from above 50 percent to about 37 percent. The decline is equally divided amongst these two sources of income. Second, there is a marked increase in the share of income from non-farm wages and from transfers. The share of other income sources such as off-farm business (at least between 1998 and 2006) and livestock and aquaculture remains relatively stable. (Note 9)

Table 3 presents the distribution of income shares conditional on expenditure quintiles for the period 1993-2006. As seen in this table, in 1993, across quintiles, households in the poorest quintile derived the smallest share of their income from crops. The share of income attributed to crops increases across quintiles reaching a peak of 38.9 percent for the fourth quintile and falling to 28.6 percent for the richest. Essentially, the level of reliance on crop income source is a concave-quadratic function of PCE level. The lowest crop income shares for the poorest can be best explained by their lower level of land holdings - for example, around 18 percent, 29 percent, and 36 percent of the poorest quintile of the rural population were landless in 1993, 1998 and in 2002 in the region (MDPA 2004). The lower share of income from this source amongst the richest households is probably due to their access to other earning opportunities such as off-farm business.

In 1993, the pattern of income shares across quintiles is quite clear in terms of the share of income from off-farm business and farm wage employment. The richest households draw the largest share of their income from off-farm business (30.7 percent). Households in the two poorest quintiles have the smallest share (roughly 15 percent) while households in other quintiles have shares that lie in between these two limits. (Note 10, Note 11) In contrast, in terms of agricultural wages, the poorest households rely most heavily on this source of income (38 percent) while for the richest households agricultural wages contribute about 5.6 percent of their income (see Table 3 ). Indeed, the poorer the household the higher its share of income from farm wages. The share of income from other income sources does not appear to be very different across different quintiles in 1993. 
Table 3. Trends of income diversification, by income shares and expenditure quintiles

\begin{tabular}{|c|c|c|}
\hline $\begin{array}{l}\frac{\grave{d}}{\mathbf{g}} \\
\text { tै }\end{array}$ & $\stackrel{\leftrightarrow}{\check{\infty}}$ & 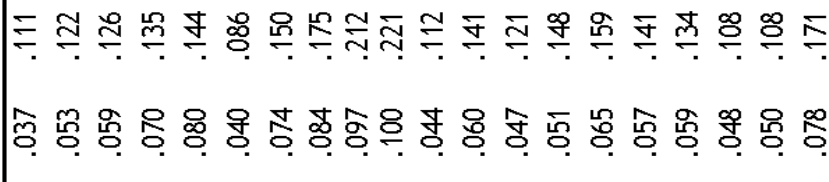 \\
\hline 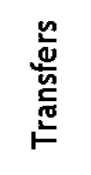 & $\stackrel{\leftrightarrow}{\check{E}}$ & 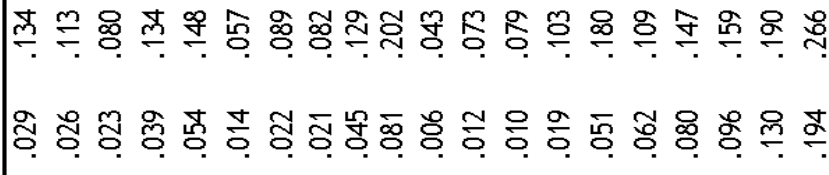 \\
\hline 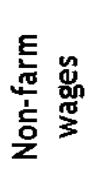 & $\stackrel{\leftrightarrow}{\check{5}}$ & 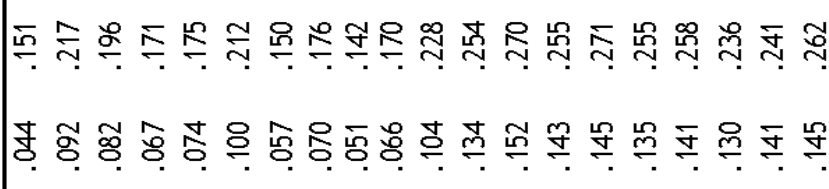 \\
\hline 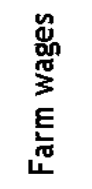 & $\stackrel{9}{\vdots}$ & 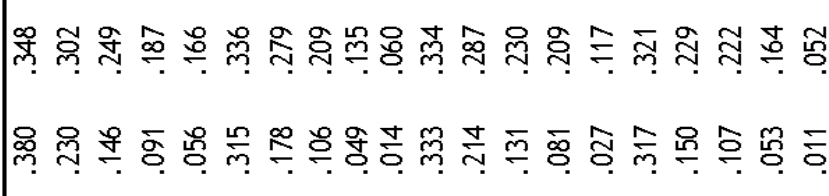 \\
\hline 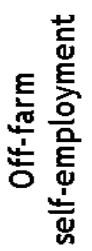 & ڤิ & 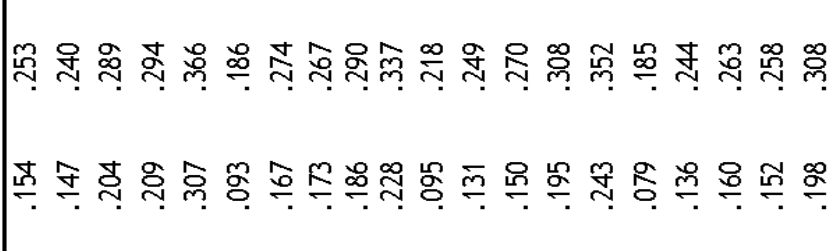 \\
\hline 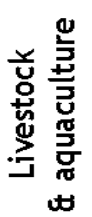 & ڤิ & 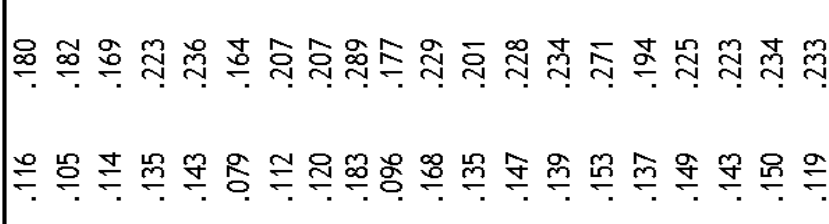 \\
\hline 气온 & $\stackrel{i}{\vdots}$ & 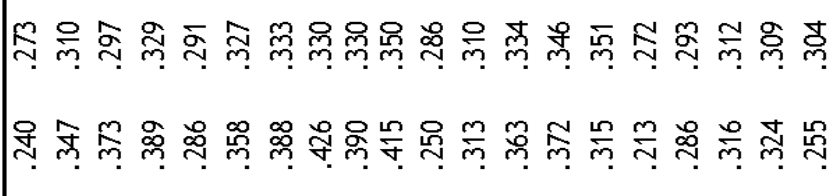 \\
\hline 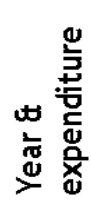 & & 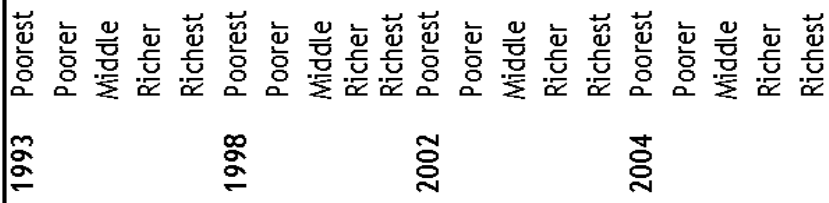 \\
\hline
\end{tabular}


Table 3 (cont.)

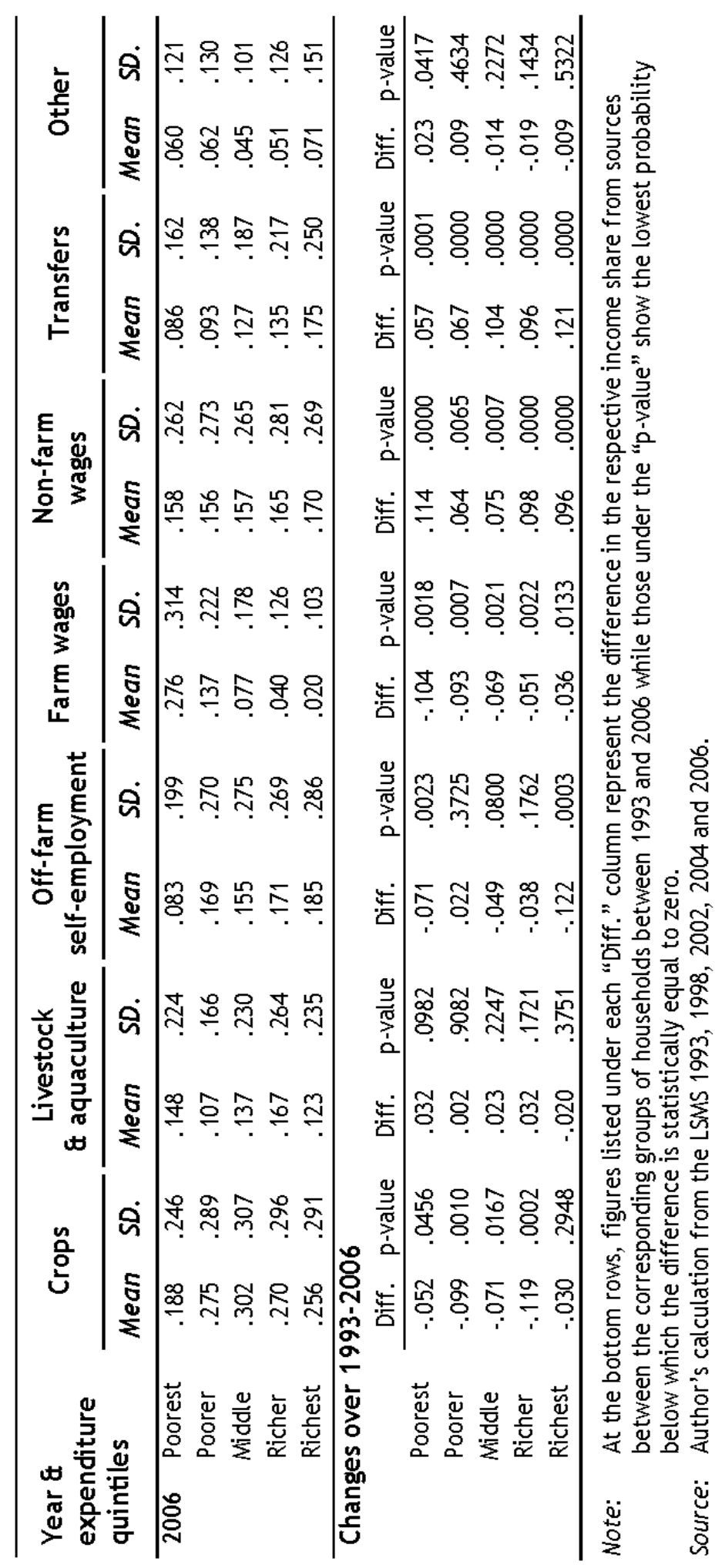

Having described the share of reliance on different income sources across expenditure quintiles in 1993, we now turn to changes between 1993 and 2006. Changes over time are provided in the bottom part of Table 3. The negative sign across all quintiles in crop income share between 1993 and 2006 indicates a movement away from this traditional 
income source among households across all quintiles. However, the level of movement away from this income source varies across quintiles. Households in the 'poorest quintile' reduce their reliance on crop income by 5.2 percentage points while those in the fourth quintile (richer) experience a reduction of 11.9 percentage points. The reduction among households in the 'richest quintile' ( 3.0 percentage points) is not statistically significant.

In term of reliance on farm wages there are clear patterns. As may be expected, given their greater reliance on farm wages in 1993, households in the poorest quintiles experience the largest drop in their reliance on farm wages as a source of income as compared to the richest. Indeed, the poorer the household the more it tends to move away from farm wages as an income source. As seen in Table 3, the average reduction is 10.4 percentage points for the poorest households while it is 3.6 percentage points for the richest households.

Over the same period, as shown in Table 3, while there is a clear decline in the role of off-farm business in contributing to household incomes there are variations across quintiles. Households in the two extremes of the consumption distribution tend to experience sharper declines ( 7.1 and 12.2 percentage points for the poorest and the richest respectively). The increasing trend of reliance on non-farm wages and transfers displayed for the entire sample is also present in every quintile. Between 1993 and 2006, households in the 'poorest quintile' experienced a 11.4 percentage point increase in the share of income from non-farm wages, the highest acceleration as compared to other quintiles.

Over this period, reliance on transfers as a source of income increases across all quintiles. From a 3 to 5 percent share in a household's income portfolio in 1993, transfers account for between 8.6 to 17.5 percent of household income in 2006. There are clear patterns across quintiles with the richest group experiencing the greatest increase in reliance on transfers (12.1 percentage points) while the poorest group experiences a more modest 5.7 percentage point increase. This pattern may be expected as according to GSO (2006) and UNFPA (2007) internal temporary migrants are more likely to come from non-poor households located in rural areas.

Overall, the patterns for the total sample show a decline in reliance on crop income and on farm employment as an income source and an increase in the share of non-farm wage employment and transfers as a source of income. Analysis of the patterns, conditional on expenditure, shows that the changes are not restricted to a particular quintile but occur across all quintiles. While the extent of the changes does differ, indeed all quintiles are less likely to rely on traditional income sources - crop income, farm wage activities, and off-farm business and are more likely to rely on non-farm wage activities and private transfers. The main point emerging from the quintile-specific analysis is that the patterns of change are not dominated by one quintile but are experienced by all quintiles. These patterns also suggest that while diversification may be driven by different motives (for the rich and the poor) the outcomes appear to be similar.

\subsection{Measure of Diversity in Shares of Earning Time Allocation}

Changes in income shares are likely to be strongly affected by changes in prices of agricultural products and wage rates, and may reflect, in part, price effects rather than changes in household decision-making with regard to allocation of labour (which are based at least partially on relative price incentives or signals). Therefore, this section uses the share of earning time devoted to various activities as a complimentary indicator of diversification. In other words, the trends of income diversification in this section focus on the input side while the trends discussed in the previous section focused on the output side. Earning time shares from various sources are displayed in Table 4 for the overall MRD and in Table 5 for each household expenditure group. In these tables, farm self-employment includes cropping, and livestock and aquaculture production - these activities are only separable on the output-side of the analysis. The other types of employment are based on the same classification as already provided in the case of income.

Starting with 1993, on average each household in the MRD spent up to 61.9 percent of its time on farm self-employment activities. Off-farm self-employment accounted for 16.2 percent (which is similar to the country average of 15.0 percent (van de Walle and Cratty 2004: Appendix A1)), while farm wage employment accounted for 14.7 percent. In this initial year, non-farm wage employment accounted for the smallest proportion of earning time (7.3 percent). Thus, seven years after the launch of the master renovation plan, households in the MRD continued to spend about 76.6 percent of their time on agriculture related activities. The rest of their time (23.4 percent) was supplied to two types of non-farm employment activities. The share of time spent on non-farm employment activities is substantially lower than the 43 percent time spent on these activities by rural households in other parts of Asia in the 1970s-1990s (Reardon et al. 1998: Table 11). 
Table 4. Trends of income diversification, by household time allocation and expenditure quintiles

\begin{tabular}{|c|c|c|c|c|c|c|c|c|c|c|c|c|}
\hline \multirow{2}{*}{ Source } & \multicolumn{2}{|c|}{$\begin{array}{c}1993 \\
(\mathrm{~N}=795)\end{array}$} & \multicolumn{2}{|c|}{$\begin{array}{c}1998 \\
(N=824)\end{array}$} & \multicolumn{2}{|c|}{$\begin{array}{c}2002 \\
(\mathrm{~N}=5014)\end{array}$} & \multicolumn{2}{|c|}{$\begin{array}{c}2004 \\
(\mathrm{~N}=1459)\end{array}$} & \multicolumn{2}{|c|}{$\begin{array}{c}2006 \\
(\mathrm{~N}=1431)\end{array}$} & \multicolumn{2}{|c|}{$2006 / 1993$} \\
\hline & Mean & $S D$. & Mean & $S D$. & Mean & $S D$. & Mean & $S D$. & Mean & $S D$. & Diff. & $p$-value \\
\hline$\overline{\text { Farm }}$ & .619 & .355 & .597 & .368 & .487 & .444 & .478 & .388 & .459 & .383 & -.160 & 0.0000 \\
\hline Off-farm self-employment & .162 & .275 & .173 & .285 & .192 & .340 & .194 & .319 & .207 & .327 & .045 & 0.0006 \\
\hline Farm wage employment & .147 & .251 & .139 & .249 & .179 & .332 & .157 & .282 & .136 & .260 & -.011 & 0.3282 \\
\hline Non-farm wage employment & .073 & .185 & .090 & .202 & .142 & .271 & .171 & .286 & .198 & .309 & .125 & 0.0000 \\
\hline
\end{tabular}

Source: Author's calculation from the LSMS 1993, 1998, 2002, 2004 and 2006.

Despite initial reforms as well as consecutive agriculture-related reforms during 1993-98, notably changes in trade policy, in 1998 the allocation of time to different activities is not very different as compared to 1993. The limited changes in time allocation may be compared with the increase in the income share from crops (a major part of farm self-employed income source) observed in section 2.6.2. The increased income share from crops combined with the slight reduction in time allocated to farm self-employment supports the idea that the increased income share from this source may be attributed largely to price increases.

It is possible that the unchanged pattern of time-allocation between 1993 and 1998 was partly due to limited access to alternative earning options. However, by 2002, there seems to be a remarkable change. The share of farm self-employment drops to 48.7 percent - a 13.2 percentage point reduction as compared to 1993 and an increase in the time allocated to non-farm wage employment from 7.3 to 14.2 percentage points. While the time allocated to farm self-employment drops the income share remains at the 1993 level suggesting increased labour productivity. At the same time the increase in the allocation of time to non-farm wage employment highlights the increasing range of such opportunities in rural areas.

Two years later in 2004, the allocation of time across different types of employment is quite similar to the pattern observed in 2002. The share of farm self-employment remains at about 48 percent while the share of non-farm wage employment increases by three percentage points to 17.1 percent. With this increase, the time allocated to non-farm wage employment no longer occupies the smallest share of a household's time. In 2006, the pattern of change continues to strengthen with the share of time spent on farm self-employment declining to 45.9 percent, while the share of non-farm wage employment climbs to 19.8 percent (see Table 4).

The last column of Table 4 provides information about changes in the pattern of income diversification across employment types in rural MRD over the period 1993-2006. As shown in the table, there is a reduction of 16 percentage points in the share of time allocated to farm self-employment over this period, with the sharpest change occurring between 1998 and 2002. At the same time there is an increase in the share of hours devoted to non-farm wage employment (12.5 percentage points). Once again the sharpest changes take place between 1998 and 2002. The decline in the share of time allocated to farm self-employment is larger (16 percentage points) than the decline in the income share of these activities (about 5.4 percentage points) suggesting that over this period households have become more productive in terms of their self-employed agriculture-related activities. In contrast the share of farm wage employment in terms of time allocation remains stable while the returns from this activity (income share) decline (7.2 percentage points) suggesting limited increase in farm wages over this period. From a supply side perspective the increase in agricultural productivity may have allowed the release of labour for alternative purposes while the increase in the number of non-farming enterprises is likely to have increased the demand for rural labour. 
Table 5. Trends of income diversification, by household time allocation and expenditure quintiles

\begin{tabular}{|c|c|c|c|c|c|c|c|c|}
\hline \multirow{2}{*}{$\begin{array}{l}\text { Year \& } \\
\text { expenditure } \\
\text { category }\end{array}$} & \multicolumn{2}{|c|}{$\begin{array}{c}\text { Farm } \\
\text { self-employment }\end{array}$} & \multicolumn{2}{|c|}{$\begin{array}{c}\text { Off-farm } \\
\text { self-employment }\end{array}$} & \multicolumn{2}{|c|}{$\begin{array}{c}\text { Farm wage } \\
\text { employment }\end{array}$} & \multicolumn{2}{|c|}{$\begin{array}{c}\text { Non-farm } \\
\text { wage } \\
\text { employment }\end{array}$} \\
\hline & Mean & $S D$. & Mean & $S D$. & $\overline{M e a n}$ & $S D$. & Mean & $S D$. \\
\hline 1993 Poorest & .533 & .379 & .110 & .228 & .312 & .340 & .045 & .166 \\
\hline \multirow{3}{*}{1993} & .630 & .341 & .107 & .216 & .188 & .264 & .075 & .183 \\
\hline & .645 & .337 & .160 & .260 & .117 & .216 & .078 & .190 \\
\hline & .708 & .317 & .153 & .262 & .074 & .151 & .065 & .165 \\
\hline Richest & .579 & .374 & .279 & .354 & .041 & .120 & .101 & .212 \\
\hline 1998 Poorest & .515 & .375 & .086 & .171 & .302 & .320 & .097 & .205 \\
\hline \multirow{3}{*}{1998} & .602 & .362 & .153 & .258 & .182 & .273 & .063 & .154 \\
\hline & .621 & .346 & .183 & .277 & .119 & .219 & .077 & .180 \\
\hline & .649 & .355 & .189 & .293 & .060 & .160 & .101 & .222 \\
\hline Richest & .599 & .389 & .260 & .367 & .027 & .095 & .114 & .235 \\
\hline 2002 Poorest & .406 & & .112 & .268 & & .433 & .118 & .260 \\
\hline Poorer & .478 & .446 & .158 & .307 & .219 & .362 & .145 & .284 \\
\hline Middle & .526 & .442 & .171 & .320 & .148 & .302 & .155 & .284 \\
\hline Richer & .526 & .431 & .217 & .346 & .109 & .255 & .148 & .263 \\
\hline Richest & .491 & & & & & .183 & .140 & .262 \\
\hline 2004 Poorest & .381 & .355 & .099 & .232 & .374 & .370 & .147 & .267 \\
\hline Poorer & .474 & .369 & .172 & .300 & .186 & .270 & .169 & .289 \\
\hline Middle & .505 & .387 & .215 & .327 & .126 & .245 & .153 & .263 \\
\hline Richer & .542 & .389 & .203 & .314 & & .207 & .181 & .282 \\
\hline Richest & .489 & .420 & .285 & .379 & & .104 & .205 & .324 \\
\hline \multirow{7}{*}{ hanges ov } & .381 & .348 & .108 & .242 & .323 & .349 & .188 & .294 \\
\hline & .423 & .363 & .219 & .329 & .170 & .268 & .188 & .315 \\
\hline & .492 & .384 & .208 & .329 & .103 & .218 & .196 & .307 \\
\hline & .509 & .404 & .241 & .342 & .058 & .165 & .192 & .305 \\
\hline & & .395 & .259 & .356 & .030 & .130 & .227 & .321 \\
\hline & \multicolumn{8}{|c|}{ hanges over 1993-2006 } \\
\hline & Diff. & $p$-value & Diff. & p-value & Diff. & p-value & Diff. & p-value \\
\hline Poorest & -.152 & .0000 & -.002 & .9308 & .011 & .0000 & .143 & .0000 \\
\hline Poorer & -.207 & .0000 & .112 & .0000 & -.018 & .4930 & .113 & .0000 \\
\hline Middle & -.153 & .0000 & .048 & .0907 & -.014 & .5133 & .140 & .0000 \\
\hline Richer & -.199 & .0000 & .088 & .0025 & -.016 & .2994 & .127 & .0000 \\
\hline Richest & -.094 & .0139 & -.020 & .5719 & -.011 & .3727 & .126 & .0000 \\
\hline
\end{tabular}

Source: Author's calculation from the LSMS 1993, 1998, 2002, 2004 and 2006.

An assessment of patterns of income diversity across expenditure quintiles and across types of employment is provided in Table 5. As shown in the table, starting with the 1993 figures, across quintiles, the time allocated to farm self-employment can be described as a quadratic function of the PCE level, with the lowest share (53.3 percent) for the poorest quintile, followed by the richest (57.9 percent) while other quintiles spend a larger proportion of their time on farm self-employment (63 to 71 percent). The share of farm wage employment is highest amongst the poorest (31.2 percent) and declines with increases in PCE and accounts for only 4.1 percent of the time of the richest households. 
Thus, in 1993, farming related activities account for 84.5 percent of the earning time of the poorest households and 62 percent of the earning time of the richest households. Off-farm self employment and non-farm wage employment account for 27.9 percent and 10.1 percent of the time allocated by richest households while the corresponding figures for the poorest are 11 and 4.5 percent respectively.

Consistent with the changes for the total sample, the picture does not change much between 1993 and 1998. However, between 1998 and 2002 and after 2002 new patterns emerge and continue to strengthen. Focusing on the figures presented in the bottom panel of Table 5 we see that the changes noted for the overall sample are not restricted to a particular expenditure quintile. Rural households in all groups tend to spend a lower proportion of their earning time on farm self-employment and more on non-farm wage employment. For instance, the share of time allocated to non-farm wage employment increases between 11.3 and 14.3 percentage points across quintiles and the gaps across quintiles are less pronounced in 2006 as compared to 1993. Similarly, the reduction in time spent on farm self-employment lies between 9 and 15 percentage points across quintiles. Thus, over time, it seems that regardless of whether the focus is on the time share or the income share indicators, households across all PCE quintiles move away from traditional occupations to non-farm wage employment. The similarity in diversification patterns across quintiles suggests a pattern of inclusive growth.

\subsection{Agricultural Commercialization as Diversification}

It is also of interest to examine agricultural commercialization as diversification in the MRD, which is conceptualized as an increase in the share of agricultural output that is sold. Table 6 provides information on the share of agricultural output that is sold among and across quintiles over time.

Table 6. Share of agricultural output that is sold, by expenditure quintile

\begin{tabular}{|c|c|c|c|c|c|c|c|c|c|c|c|c|}
\hline \multirow{2}{*}{$\begin{array}{l}\text { Expenditure } \\
\text { category }\end{array}$} & \multicolumn{2}{|c|}{$\begin{array}{l}1993 \\
(N=676)\end{array}$} & \multicolumn{2}{|c|}{$\begin{array}{l}1998 \\
(N=684)\end{array}$} & \multicolumn{2}{|c|}{$\begin{array}{l}2002 \\
(N=4044)\end{array}$} & \multicolumn{2}{|c|}{$\begin{array}{l}2004 \\
(N=1195)\end{array}$} & \multicolumn{2}{|c|}{$\begin{array}{l}2006 \\
(N=1166)\end{array}$} & \multicolumn{2}{|c|}{$2006 / 1993$} \\
\hline & Mean & $S D$. & Mean & $S D$. & Mean & $S D$. & Mean & $S D$. & Mean & $S D$. & Diff. & $\begin{array}{c}p \text {-val } \\
\text { ue }\end{array}$ \\
\hline Poor & .560 & .254 & .658 & .227 & .745 & .220 & .744 & .208 & .730 & .234 & .170 & .0000 \\
\hline Poorer & .594 & .219 & .681 & .217 & .794 & .180 & .771 & .184 & .792 & .185 & .198 & .0000 \\
\hline Middle & .620 & .244 & .724 & .206 & .829 & .161 & .821 & .153 & .828 & .156 & .208 & .0000 \\
\hline Richer & .683 & .205 & .772 & .186 & .843 & .158 & .833 & .151 & .857 & .137 & .174 & .0000 \\
\hline Richest & .700 & .219 & .774 & .192 & .874 & .149 & .853 & .170 & .862 & .171 & .162 & .0000 \\
\hline Overall & .634 & .234 & .724 & .211 & .818 & .180 & .804 & .178 & .814 & .185 & .199 & .0000 \\
\hline
\end{tabular}

Notes: The number of observation is 676, 684, 4,044, 1,195, and 1,166 respectively for the 1993, 1998, 2002, 2004 and 2006 sample. Households without any agricultural production are excluded.

Source: Author's calculation from the LSMS 1993, 1998, 2002, 2004 and 2006.

The overall share of agricultural output that is sold increases from 63.4 percent in 1993 to 81.4 percent in 2006. The change is uniform across quintiles with increases in the share of output sold of between 16 to 21 percentage points. It is likely that this rapid growth reflects an increased degree of market integration (increases in prices of agricultural produce) which may be a result of the implementation of economic reforms, notably trade liberalization policies during 1993-1998, under the renovation program in Vietnam as presented in section 2.3.1. Apart from sales, the remaining quantity of output produced is kept for home consumption, mainly foods and animal feed. An increased rate of commercialization does not mean a reduction in the amount of home consumption. Instead of self-subsistence on home-produced outputs, households may prefer to buy processed foods, for example milled rice, for their consumption and cattle-feed for animal husbandry using the money received from selling home-produced commodities. The increase in the share of produce that is sold reflects a combination of an increase in productivity which allows sales of a greater proportion of output as well as an increase in the price of agricultural products. However, the main point here is that while diversification is occurring in terms of movement away from traditional sources of income, even within the traditional sources of income there is a movement away from traditional practices and a greater reliance on markets. 


\section{Concluding Remarks}

Based on five LSMSs conducted over a thirteen year period (1993 to 2006), this paper examined patterns of income diversification in rural areas of the MRD.

While the paper relied on a number of measures of diversification it paid special attention to assessing income diversification from the input side, in terms of time spent on different activities, and from the output side, in term of income shares attributable to different sources. On the input side, the time spent on farm self-employment declined by 16 percentage points while time spent on non-farm wage employment rose by 12.5 percentage points. Time spent on other activities such as off-farm self-employment and farm-wage employment remained relatively stable. On the output side, the importance of income from crops, off-farm self-employment and farm wage employment declined by about 5 to 7 percentage points for each source while the share of non-farm wage employment and transfers increased by about 9 percentage points each.

In terms of quintile specific patterns, over the period 1993-2006, across all quintiles there is a sharp reduction in the time spent on farm self-employment (9.4 to 20.7 percentage points) and an increase in the share of time spent on non-farm wage employment (11.3 to 14.3 percentage points). While there are differences across quintiles, the patterns are broadly similar across expenditure groups and it does not seem that the increase in non-farm wage employment is restricted to particular groups of households. As may be expected given the changes in the activity-allocation pattern, over time, there is an increase in reliance on non-farm wage income by about 6.4 to 11.4 percentage points across quintiles. The interesting aspect is that while households in the poorest income quintiles still continue to rely heavily on agriculture related income (61.2 versus 39.9 percent for the richest quintile) they experience similar patterns of change in terms of a movement from relying on farm income to non-farm sources of income. While the factors that drive diversification is not the subject of this paper, the similar patterns experienced across different quintiles suggests that the movement towards non-farm wage employment may be driven by policy changes that affect the entire economy and not just specific groups of households.

\section{References}

Abdulai, A., \& CroleRees, A. (2001). Determinants of Income Diversification amongst Rural Households in Southern Mali. Food Policy, 26(4), 437-452.

Barrett, C. B., \& Reardon, T. (2001). Asset, Activity, and Income Diversification Among African Agriculturalists: Some Practical Issues. Food Policy, 26(4), 315-331.

Barrett, C. B., Reardon, T., \& Webb, P. (2001). Nonfarm Income Diversification and Household Livelihood Strategies in Rural Africa: Concepts, Dynamics, and Policy Implications. Food Policy, 26, 315-331.

Benjamin, D., \& Brandt, L. (2002). Agriculture and Income Distribution in Rural Vietnam under Economic Reforms: A Tale of Two Regions. In P. Glewwe et al. (Eds.), Economic growth, poverty, and household welfare in Vietnam (pp. 133-186). Washington, DC: World Bank.

Carney, D., Drinkwater, M., Rusinow, T., Neefjes, K., Wanmali, S., \& Singh, N. (1999). Livelihoods Approaches Compared: A brief comparison of the livelihoods approaches of the UK Department for International Development (DFID), CARE, Oxfam and the United Nations Development Programme (UNDP). London: Department for International Development.

Davis, J. R. (2003). The Rural Non-farm Economy, Livelihoods and their Diversification: Issues and Options. NRI Report to Department for International Development and World Bank no. 2753.

Davis, J. R., \& Bezemer, D. (2003). Key Emerging and Conceptual Issues in the Development of the RNFE in Developing Countries and Transition Economies. NRI Report to Department for International Development and World Bank no. 2753.

Ellis, F. (1998). Household Strategies and Rural Livelihood Diversification. Journal of Development Studies, 35(1), 1-38.

Ellis, F. (2000). Rural Livelihoods and Diversity in Developing Countries. New York: Oxford University Press.

Glewwe, P. (2004). An Overview of Economic Growth and Household Welfare in Vietnam in the 1990s. In P. Glewwe et al. (Eds.), Economic Growth, Poverty, and Household Welfare in Vietnam (pp. 1-26). Washington D.C.: World Bank Regional and Sectoral Studies.

GSO and UNFPA. (2005a). The 2004 Vietnam Migration Survey: Major Findings. Hanoi: General Statistical Office.

GSO and UNFPA. (2005b). Dieu Tra Di Cu Viet Nam nam 2004: Chat Luong Cuoc Song Cua Nguoi Di Cu o Viet Nam 
(The 2004 Vietnam Migration Survey: Quality of Life for Internal Migrants in Vietnam). Hanoi: General Statistical Office.

GSO. (2002). Statistical Yearbook. Hanoi: Statistical Publishing House.

GSO. (2004a). Nien Giam Thong Ke 12 Tinh Dong Bang Song Cuu Long va Kinh Te Viet Nam Trong Nhung Nam Doi Moi 1999-2000 (Statistical Yearbooks of 12 Provinces in the Mekong Delta and Vietnam Economy in the Transition Period, 1991-2000). Hanoi: Statistical Publishing House.

GSO. (2004b). Result of the Survey on Households Living Standards 2002. Hanoi: Statistical Publishing House.

GSO. (2006a). The 2004 Vietnam Migration Survey: Internal Migration and Related Life Course Events. Hanoi: General Statistical Office.

GSO. (2006b). Nien Giam Thong Ke Cac Tinh Dong Bang Song Cuu Long 2000-2005 (Statistical Yearbook on the Mekong Delta, Vietnam 2000-2005). Hanoi: Statistical Publishing House.

GSO. (2006c). So Tay Huong Dan Nghiep Vu (VHLSS 2006 Guidelines for Interviewers), Khao Sat Muc Song Gia Dinh Ho 2006 (Vietnam Household Living Standards Survey 2006). General Statistics Office.

GSO. (2007). Result of the Survey on Households Living Standards 2004. Retrieved from rom www.gso.gov.vn

GSO. (2008). Result of the Survey on Households Living Standards 2006. Hanoi: Statistical Publishing House.

Haughton, J. (2001). Introduction: Extraordinary changes. In D. Haughton et al. (Eds.), Living Standards During an Economic Boom: The case of Vietnam (pp. 95-119). Hanoi: Statistical Publishing House.

Joshi, P. K., Gulati, A., Birthal, P. S., \& Twari, L. (2003). Agricultural Diversification in South Asia: Patterns, Determinants, and Policy Implications. Washington D.C.: International Food Policy Research Institute: Markets and Structural Studies Division.

Lanjouw, P. (2006). Does the Rural Nonfarm Economy Contribute to Poverty Reduction?. In S. Haggblade et al. (Eds.), Transforming the Rural Nonfarm Economy: Opportunities and Threats in the Developing World. Baltimore: Jonhs Hopkins University Press.

Lanjouw, P. (2007). Does the Rural Nonfarm Economy Contribute to Poverty Reduction?. In S. Haggblade et al. (Eds.), Transforming the Rural Nonfarm Economy: Opportunities and Threats in the Developing World (pp. 55-81). Baltimore: Johns Hopkins University Press.

Minot, N., \& Goletti, F. (1998, November). Export Liberalization and Household Welfare: the Case of Rice in Vietnam. American Journal of Agricultural Economics, 138-149.

Minot, N., Epprecht, M., Anh, T. T. T., \& Trung, L. Q. (2006). Income Diversification and Poverty in the Northern Uplands of Vietnam. Washington, DC: International Food Policy Research Institute.

UNDP. (2004). The Regional Poverty Assessment Mekong River Region. Hanoi: UNDP.

UNDP. (2005). MDGs and Viet Nam's Socio-Economic Development Plan 2006-2010. UNDP. Retrieved from http://www.undp.org.vn/undpLive/digitalAssets/9/9935_mdgsedpe.pdf.

Walle, D. van de. (1998). Infrastructure and Poverty in Vietnam. In D. Dollar et al. (Eds.), Household welfare and Vietnam's transition (pp. 99-134). Washington, D.C.: The World Bank.

Walle, D. van de., \& Cratty, D. (2004). Is the Emerging Non-farm Market Economy the Route Out of Poverty in Vietnam?. The Economics of Transition, 12(2), 237-274.

World Bank. (1995). Viet Nam Living Standards Survey (VLSS), 1992-93: Basic Information. Research Development Group, World Bank.

World Bank. (1999). Vietnam Development Report 2000: Attacking Poverty. Washington DC.,: Poverty Reduction and Economic Management Unit, East Asia and Pacific Region.

\section{Notes}

Note 1. For details on these indices see Barrett and Reardon (2001) for the Herfindahl index, Ellis (2000) for the inverse Herfindahl index, and Minot (2003) for the Simpson index.

Note 2. Production costs of livestock and aquaculture were combined in the questionnaire used in LSMS 1993 and 1998. Accordingly, income from these two sources is combined into one for 1993 and 1998. To enable comparisons 
across time, although information about livestock and aquaculture produce were collected separately in later surveys, combined information is presented even for the survey years 2002, 2004 and 2006.

Note 3. Except for the survey conducted in 2002, it is possible to make a distinction between earnings from a primary job, earnings from a secondary job and earnings from other jobs. In the case of the 2002 survey, information is restricted to earnings from a primary job and other jobs, including the secondary job are lumped together. Thus, for 2002 the earnings information is restricted to earnings from the primary job while earnings from other jobs including the secondary job appear as other income.

Note 4. Time spent by household members on their most time-consuming and second most time-consuming job is used to calculate allocation of time across various activities except for 2002. In 2002, the data collected did not make a distinction between secondary jobs and other jobs and hence in 2002, total household working time is defined as the sum of working time spent by all household members allocated to each member's most time-consuming activity only.

Note 5. While there is not much change in the number of sources of income between 1993 and 2006, the table shows a decline in number of income sources for all quintiles as well as for the whole sample in 2002. The reason for the dip in 2002 and the return to the 1993/1998 pattern in 2004 and 2006 is not clear.

Note 6. For example, agricultural self-employed activities provided up to 61.5 percent of farm household incomes in Guangdong (China) in 1990. Similarly, such activities accounted for 53.2 percent of household income in Mindanao (Philippines) in 1985/86 (computed from Delgado and Siamwalla 1997: Table 2). Non-farm employment activities in the MRD account for 27.6 percent of rural household income. This is comparable to 32 percent in Asia, 35 percent in East-Asia between 1970s and 1990s (Reardon et al. 1998), 30 percent in Vietnam as a whole in 1993, and 33.8 percent in Guangdong in 1990 (Delgado and Siamwalla 1997).

Note 7. The price of rice was lower in 2002 than in 1998. This as well as the fluctuating price of this commodity can be seen in Table 3.2 in the next paper.

Note 8 . The increase in the non-farm wage employment share in total income leads to an increase in the share of non-farm income (off-farm business and non-farm wage employment) to 31.4 percent. For a comparison, this similar account was about 38 percent in selected villages in rural China in 2000 (Xiaoping 2007) and 50 percent of household income in rural China as a whole in 2001 (Janvry et al. 2005).

Note 9. The empirical picture provided here is similar to the story in other synthesis studies, for example Carletto et al. (2007) and Reardon et al. (1998) which report the growing importance of non-farm employment over time, including non-farm wage employment, across developing and transition economies.

Note 10. The difference in the share of income from off-farm business between the two poor groups is not supported by a t-test.

Note 11. These patterns are not uniform across countries. The situation in Vietnam is similar to the situation observed in Ecuador (1995), but different from the situation in Kenya (1975) and Pakistan (1989). Ethiopia (1990) and India (1999) display structures that are neutral across expenditure groups (Lanjouw 2006: Table 3.1). 